\title{
Bacillus sp. ile iyileştirilmiş zeminlerin donma çözülme etkisindeki davranışı
}

\author{
The behavior of Bacillus sp. improved soils under freeze-thaw effect
}

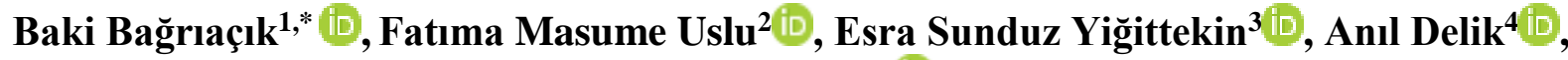 \\ Sadık Dinçer 5 (iD \\ ${ }^{1}$ Çukurova Üniversitesi, Inşaat Mühendisliği Bölümü, 01330, Adana, Türkiye \\ 2,3,4,5 Çukurova Üniversitesi, Biyoloji Bölümü, 01330, Adana, Türkiye
}

\section{Özet}

Son yıllarda, özellikle büyük kentlerde artan nüfusa bağlı olarak arazi kullanımı git gide artmaktadır. Bu durumda, temel zemini bakımından yeterli kriterli sağlayan arazilerin kullanımının yanı sıra bu kriterleri sağlamayan arazilerin kullanımını da zorunlu hale getirmiştir. Temel zemini bakımından yeterli kriterleri sağlamayan arazilerde, kireç, uçucu kül, yüksek firın cürufu gibi katkılarla zemin iyileştirme yapılarak istenilen kriterlere ulaşılmaktadır. Ancak bu katkılar doğada $\mathrm{CO}_{2}$ salınımını artırdığı için çevre dostu değillerdir. Bu nedenle, bu katkıların yerini yeni nesil çevre dostu zemin iyileştirme katkıları almaktadır. Bu katkılardan bir tanesi enjekte edildiği zemin içerisinde $\mathrm{CaCO}_{3}$ üreterek iyileşme sağlayan Bacillus Sp.'dir. Bu bağlamda çalışma kapsamında, yüksek plastisiteli kil $(\mathrm{CH})$ ve kumlu kil (SC) türü iki farklı zemin türünde yeni nesil iyileştirme katkısı olan Bacillus Sp. kullanılarak, donma çözülme döngüleri altında mukavemet ve şişme basıncı davranışları araştırılmıştır. Sonuçlara göre, Bacillus Sp.'nin $\mathrm{CH}$ ve $\mathrm{SC}$ türü zeminlerde, mukavemet ve şişme basıncı parametrelerinin iyileştirilmesinde olumlu yönde katkısı olduğu belirlenmiştir.

Anahtar kelimeler: Zemin iyileştirme, Bacillus sp. Serbest basınç mukavemeti, Şişme basıncı

\section{Giriș}

Zemin iyileştirme yöntemleri, zeminlerin mühendislik özellikleri bakımından yetersiz kalması halinde derin temel sistemlerine alternatif bir yöntem olarak son y1llarda sıklıkla kullanılmaktadır. Bu yöntemlerin, derin temel sistemlerine göre daha ekonomik olması ve problemin çözüm süresi daha hızlı olması nedeniyle sıklıkla tercih edilmektedir. Zemin iyileştirme yöntemleri arasından çeşitli katkı malzemelerinin kullanımına yönelik çalışmalar yapılmaktadır. Bu bağlamda, çok sayıda araştırmacı, çimento [1], kireç [2], uçucu kül [3], fırın cürufu [4], geri dönüştürülmüş beton agregaları [5], jeopolimer tozu [6], cam lifi [7], kenaf lifi [8], mermer tozu [9-11] gibi katkılar kullanmaktadırlar. Bu katkılar, genellikle üretimi ve/veya kullanımı sırasında çevreye $\mathrm{CO}_{2}$ gibi bazı doğaya zarar verecek gaz salınımları meydana gelmektedir.

$\mathrm{Bu}$ yüzden, bu katkılara alternatif olarak zeminlerin iyileştirilmesinde bakteriyel kalsiyum karbonat $\left(\mathrm{CaCO}_{3}\right)$ kullanımı, yeni ve çevre dostu bir yaklaşım olarak git gide

\section{Abstract}

In recent years, the need for land has been increasing due to the increasing population, especially in big cities. In addition to the use of lands that meet sufficient criteria in terms of foundation soils, it has become compulsory to use lands that do not meet these criteria. In lands that do not meet sufficient criteria in terms of basic soils, improvement is made by using classical additives such as lime, fly ash, blast furnace slag. However, these additives are not environmentally friendly as they increase $\mathrm{CO}_{2}$ emissions in nature. Therefore, in recent years, there has been an interest in new environmentally friendly additives alternative to these additives. One of these additives is Bacillus $\mathrm{Sp}$. which provides improvement in the soils by producing $\mathrm{CaCO}_{3}$ in the soil where it is injected. In this study, strength and swelling pressures were investigated under freeze-thaw cycles on high plasticity clay $(\mathrm{CH})$ and sandy clay $(\mathrm{SC})$ soils injected with Bacillus Sp. According to the results, it was determined that Bacillus Sp. contributed positively to the improvement of the strength and swelling pressure parameters of soils.

Keywords: Soil improvement, Bacillus sp., Strength, Swelling pressure

önem kazanmaktadır [12]. Bu çevre dostu yaklaşımda, bakteriler tarafindan harekete geçirilen kalsit çökeltisi kullanılarak, zeminlerin mühendislik özellikleri iyileştirilebilmektedir. Zemin iyileştirmesi esnasında, bakterilerin kalsit biriktirme sürecindeki ana rolü, çeşitli fizyolojik eylemler sırasında alkali bir ortam üretme yeteneği ile bağlantılıdır [13]. Bakteriler kullanılarak, ürenin $\mathrm{CO}_{2}$ ve amonyağa hidrolizini katalize ederek, bakteriyel ortamda $\mathrm{pH}$ ve karbonat konsantrasyonunda bir artış meydana gelmesi sağlanır [14]. Böylece, bu bakteriler vasıtasıyla, bakteriyel kalsiyum karbonat çökeltileri meydana gelmiş olur. Bu bakteriler arasında, yüksek üreaz üretimi sergileyen Bacillus pasteurii bakterileri $\mathrm{CaCO}_{3}$ çökelmesinde önemli rol oynamaktadır $[15,16]$. Literatürde bakıldığında, bu bakterinin, zeminlerin geçirgenliğinin azaltılması ve/veya mukavemet özelliklerinin artırılmasına yönelik çalışmalar bulunduğu gözlenmiştir. Yapılan araştırmalarda, araştırmacılar farklı özelliklere sahip bazı zeminlerde

\footnotetext{
* Sorumlu yazar / Corresponding author, e-posta / e-mail: bbagriacik@cu.edu.tr (B. Bağrıçık)

Geliș / Recieved: 17.03.2021 Kabul / Accepted: 03.07.2021 Yayımlanma / Published: 27.07.2021

doi: $10.28948 /$ ngmuh. 898554
} 
üretilen kalsit miktarına bağlı olarak zemin geçirgenliğinde, Whiffin vd. [17] tarafindan \% 22-\% 75, Yasuhara vd. [18] tarafindan \% 60-\% 70, Soon vd. [19] tarafindan \% 90, Nemati ve Voordouw [20] tarafindan \%98'lere varan oranlarda azalmalar meydana geldiği bildirilmiştir. Ayrıca, Ferris vd. [21] ve Ivanov ve Chu [22] gibi araștırmacılar da zemin geçirgenliğinde kayda değer oranlarda azalmalar meydana geldiğini ifade etmişlerdir. Literatürdeki sonuçlara göre, bu tür kalsit üreten bakterilerin, zeminlerin geçirgenliğinin azaltılmasında kullanılabileceğini göstermiştir. Ayrıca, yine bu tür kalsit üreden bakterilerin zeminlerin dayanım parametrelerinin araștırıldığı çalışmalar da mevcuttur [12, 17-24]. Bu çalışmalarda, araştırmacılar bu bakterilerin ürettikleri kalsit nedeniyle, zeminlerin sertliklerinin arttığı, penetrasyon kabiliyetinin azaldığı, basınç mukavemetinin önemli ölçüde arttığı, sıkışabilirliğinin ve kesme mukavemetinin iyileştiği ifade edilmiştir.

Literatüre bakıldığında, Bacillus Sp. ile iyileștirilmiş zeminlerin mukavemet ve konsolidasyon özelliklerinin iyileştirilmesine yönelik çalışmalar mevcuttur. Ancak, Bacillus Sp. ile iyileştirilmiş zeminlerin donma çözülme döngüleri altında literatürde yapılan herhangi bir çalıșmaya rastlanmamıştır. Bu nedenle, çalışma kapsamında, Bacillus Sp. ile iyileştirilmiş $\mathrm{CH}$ ve $\mathrm{SC}$ türü iki farklı zemin türünde, donma çözülme döngüleri altında mukavemet ve şişme basıncı davranışları araştırılmıştır.

\section{Materyal ve metot}

Çalışmada, kullanılan iki farklı tip zemin araziden getirildikten sonra ilk olarak kurutulmuş sonrasında ise elek analizi deneyleri yapılmıştır. Yapılan elek analizleri sonuçlarına göre, elde edilen gradasyon eğrileri Şekil 1'de verilmiştir. Yapılan deneyler sonucunda, zeminlerin sınıfları, TS 1500 [25]'e göre yüksek plastisiteli kil $(\mathrm{CH})$ ve kumlu kil (SC) olarak belirlenmiştir. $\mathrm{CH}$ zeminin likit limit değeri yaklaşık olarak \%55, plastik limit değeri yaklaşık olarak \%25 ve dane birim hacim ağırlık değeri $26.8 \mathrm{kN} / \mathrm{m}^{3}$, SC zeminin ise likit limit değeri yaklaşık olarak \%28, plastik limit değeri yaklaşık olarak \%16 ve dane birim hacim ağırlık değeri $26.4 \mathrm{kN} / \mathrm{m}^{3}$ olarak saptanmıştır.

Bakteri izolasyonu için Thuja orientalis (doğu mazısı) ve Pinus pinea (fıstık çamı) ağaçlarından zemin numuneleri toplanmıştır. Her numuneden 2 gr tartılarak $10 \mathrm{ml}$ steril serum fizyolojik içinde vortekslenerek homojenize edildikten sonra zemin süspansiyonu 850 C'de 15 dakika inkübe edilerek istenmeyen spor oluşturan bakteriler yok edilmiştir. İnkübasyonun sonunda, her bir numuneden 100 $\mu 1$, yayma yöntemi ile üre agar plağına ekilerek $3700{ }^{\circ} \mathrm{C}$ 'de 24 saat inkübe edildi. İzole edilmiş mikroorganizmaların tanımlanması için $16 \mathrm{~S}$ ribozomal DNA dizisi, bilinen dizilerle karşılaştırma için bir çevrim içi veri tabanına (NCBI DNA dizisi veri tabanı) sunulmuştur. $\mathrm{Bu}$ çalışmada kullanılan bakteriler Bacillus Sp. olarak tanımlanmıștır (Erişim numarası: NR_1149191.1). Deneysel çalışma için üre ortamı olarak "Nutrient broth powder 3g.L-1, Urea 20 gL-1, $\mathrm{NH}_{4} \mathrm{Cl}$ 10g.L-1, $\mathrm{NaHCO}_{3}$ 2.12g.L-1" kullanılmıştır [24]. Üre ortamının tüm bileşeni çözünene kadar $900 \mathrm{~mL}$ damıtılmış su içinde karıştırılmıştır ve elde edilen üre ortam çözeltisinin pH'ı 6.0'a olarak ayarlanmıştır. Daha sonra son hacme $(1 \mathrm{~L})$ ulaşmak için damıtılmış su eklenerek $120^{\circ} \mathrm{C}^{\prime} \mathrm{de}$ 15 dakika otoklavlandı. Otoklav işleminin sonunda, üre ortamına $20 \mathrm{ml}$ hacimde kalsiyum klorür çözeltisi $\left(\mathrm{CaCl}_{2}\right.$. $2 \mathrm{H}_{2} \mathrm{O} 18.5 \mathrm{~g} / 100 \mathrm{~mL}$ ) ilave edildi.

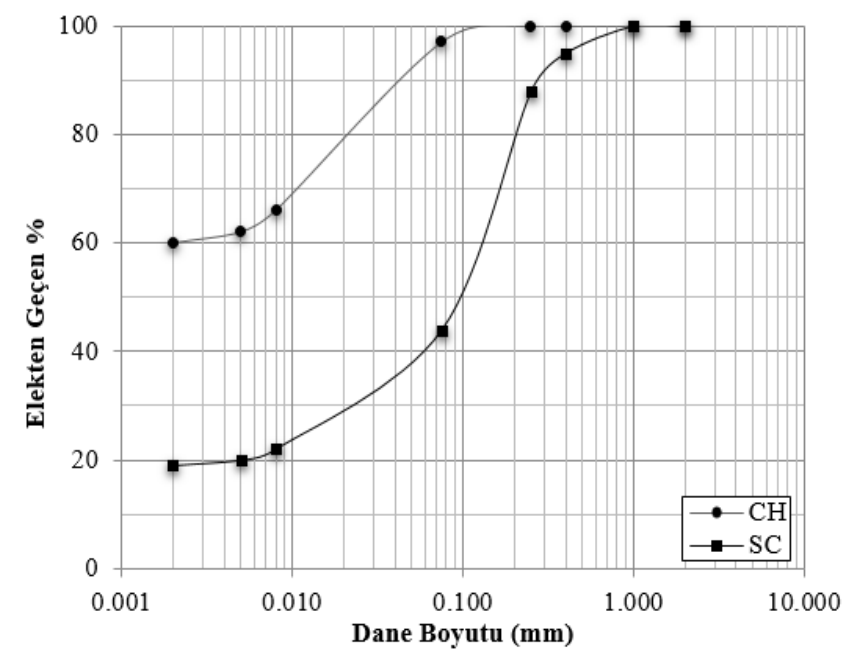

Şekil 1. CH ve SC zeminlerinin gradasyon eğrileri

$\mathrm{CH}, \mathrm{SC}$, Bacillus Sp. enjekte edilmiş $\mathrm{CH}$ ve $\mathrm{SC}$ zeminleri için numuneler oluşturulduktan sonra su muhtevalarında değişiklik olmaması için desikatörlerde bekletilmiştir. Hazırlanan numuneler literatürdeki çalışmalardaki sıcaklık, zaman dilimi ve çevrim sayılarına uygun olarak [26-30] donma çözülme döngülerine maruz bırakılmıștır. Donma çözülme çevrim sayısı $1,3,5$ ve 10 , sıcaklık değerleri donma için $-20{ }^{\circ} \mathrm{C}$ ve çözülme için $+25{ }^{\circ} \mathrm{C}$, her bir sıcaklıkta bekleme süresi ise 6 saat olarak alınmıştır. Numuneler, donma-çözülme kabinine folyo ile sarılmış ve deney süresince donma-çözülme kabininden çıkarılmamıştır. Numuneler, donma-çözülme kabinine konulduktan sonra, ilk olarak $-20{ }^{\circ} \mathrm{C}$ 'ye getirilerek 6 saat beklenmiş ve sonrasında $+25{ }^{\circ} \mathrm{C}$ 'ye getirilerek 6 saat daha beklenmiştir. 12 saatin sonunda tamamlanan bu işlem ise 1 çevrim olarak kabul edilmiştir [26, 29, 30]. Numunelerin çevrimleri tamamlandıktan sonra, TS 1500 [25] ve TS 1900 [31]'e göre serbest basınç mukavemeti ve şişme basıncı deneyleri yapılarak sonuçlar değerlendirilmiştir.

\section{Bulgular ve tartışma}

\subsection{Iyileştirilmemiş zeminlerin mukavemet ve şişme basıncı parametreleri}

Şekil 2'de, CH ve SC zeminlerinin farklı donma çözülme döngüleri sonrasında serbest basınç mukavemetleri görülmektedir. Şekil 3'te ise, her iki zeminin donma çözülmeye bağlı olarak mukavemetlerindeki azalma oranları bulunmaktadır. Sonuçlara göre, artan döngü sayılarına bağlı olarak $\mathrm{CH}$ zemininde mukavemet değerlerinde $\% 83.3$ oranında azalmalar meydana gelirken SC zemininde ise \% 88.6 oranında azalmalar meydana gelmiştir. Aynı döngü sayısında SC zeminin de mukavemet değerlerinde daha fazla azalmanın olmasının sebebi, bu zemin içinde $\mathrm{CH}$ zeminine göre daha büyük taneciklerin bulunmasından kaynaklandığı düşünülmektedir. Donma çözülmeye bağlı olarak, bu 
taneciklerin birbirinden daha çabuk ayrılarak dağılması sonucunda da mukavemetin daha fazla düştüğü düşünülmektedir.

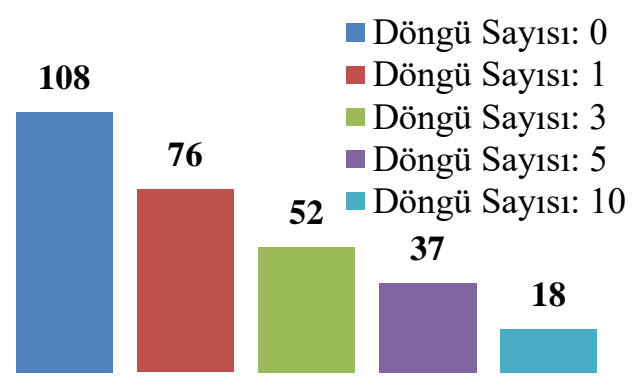

Serbest Basınç Mukavemeti (kPa) a- $\mathrm{CH}$ zemini

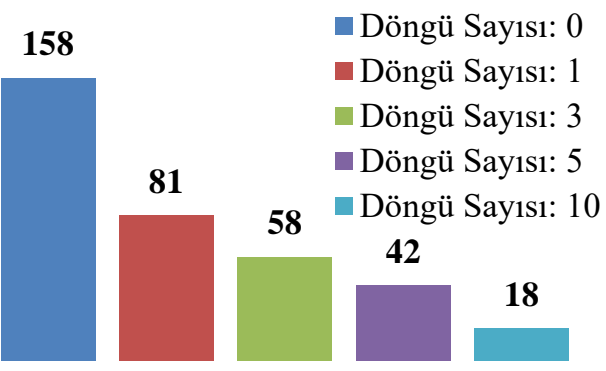

Serbest Basınç Mukavemeti (kPa) b- SC zemini

Şekil 2. Serbest basınç mukavemetleri

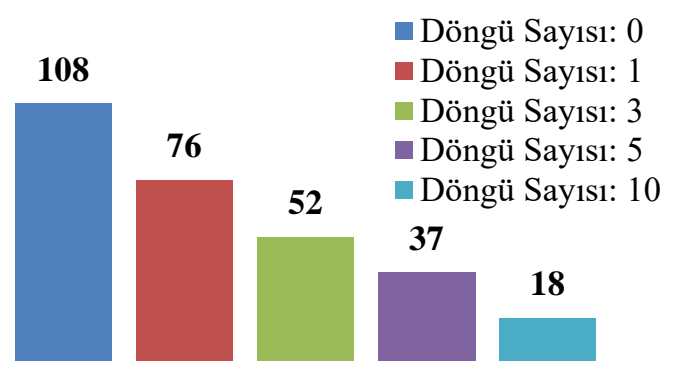

Serbest Basınç Mukavemeti (kPa)

a- $\mathrm{CH}$ zemini

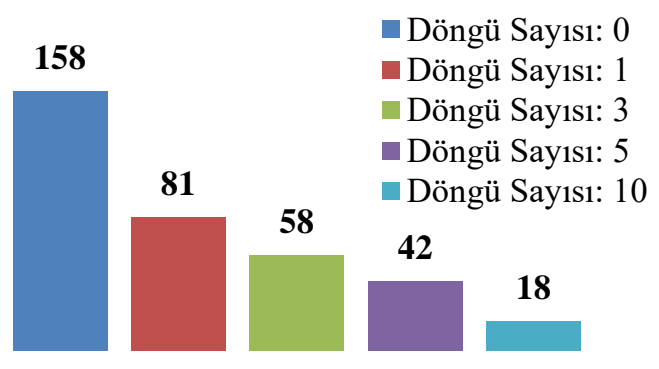

Serbest Basınç Mukavemeti (kPa)

b- SC zemini

Şekil 3. Serbest basınç mukavemetlerindeki azalmalar

Şekil 4'te, her iki zemine ait farklı döngülerdeki şişme basınçları ve Şekil 5'te ise her iki zemin içinde şişme basınçlarındaki artışlar görülmektedir. Sonuçlara göre, $\mathrm{CH}$ zeminin şişme basınçları artan döngü sayılarına bağlı olarak şişme basınçları $37.7 \mathrm{kPa}$ 'dan $54.1 \mathrm{kPa}$ a kadar yükseldiği belirlenmiştir. $\mathrm{CH}$ zeminin şişme basıncı değerlerinde, \% 30.3'e varan artışlar meydana gelmiştir. Ayrıca, SC zeminin şişme basınçları artan döngü sayılarına bağlı olarak şişme basınçları $27.7 \mathrm{kPa}$ 'dan $35.6 \mathrm{kPa}$ ' a kadar yükselerek \% 22.3'e varan artışlar meydana gelmiştir. $\mathrm{CH}$ zemininin, $\mathrm{SC}$ zeminine göre artan döngü sayılarında şişme basınçlarındaki artışların daha da fazla olmasının sebebinin $\mathrm{CH}$ zemini içindeki ince dane oranının daha fazla olması olarak düşünülmektedir. $\mathrm{CH}$ içindeki, ince dane oranının fazla olmasına bağlı olarak ta zemin içindeki suyun drenesinin SC zeminine göre daha da zorlaştığ 1 görülmüştür. Bu durum da, $\mathrm{CH}$ zeminin şişme basınçlarının daha da yüksek çıkacağını göstermektedir.

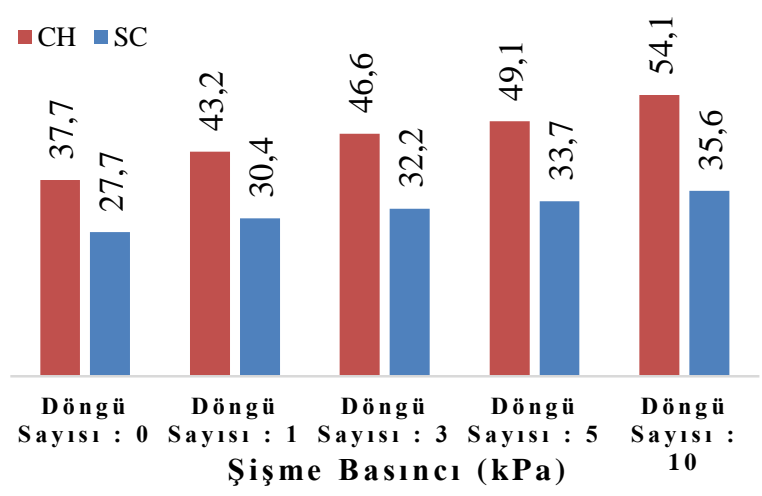

Şekil 4. Şişme basınçları

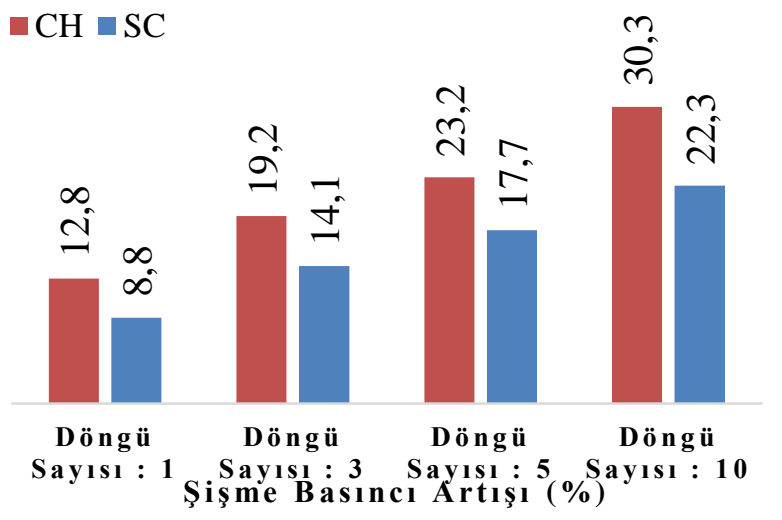

Şekil 5. Şişme basınçlarındaki artışlar

3.2 Bacillus sp. ile iyileştirilmiş zeminlerin mukavemet ve şişme basınc parametreleri

Şekil 6'da ve Şekil 7'de, CH ve SC zeminlerinin farklı donma çözülme döngüleri sonrasında serbest basınç mukavemetleri ve mukavemet değerlerindeki azalma oranları görülmektedir. Bacillus $\mathrm{Sp}$. enjekte edilerek güçlendirilen $\mathrm{CH}$ ve $\mathrm{SC}$ zeminlerinde, artan döngü sayılarına bağlı olarak sırasıly $121 \mathrm{kPa}$ 'dan $64 \mathrm{kPa}$ 'a ve $206 \mathrm{kPa}$ 'dan $120 \mathrm{kPa}$ 'a kadar mukavemet değerleri elde edilmiş ve yaklaşık olarak \% 47.1 ve \% 41.7 oranlarında azalmalar meydana gelmiştir. SC zemininde, artan döngü sayılarına bağlı olarak mukavemet değerlerindeki azalma oranının daha düşük çıkmıştır. 


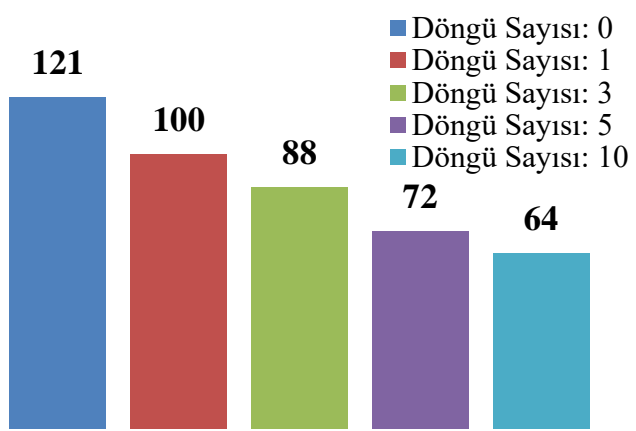

Serbest Basınç Mukavemeti (kPa)

a- $\mathrm{CH}$ zemini

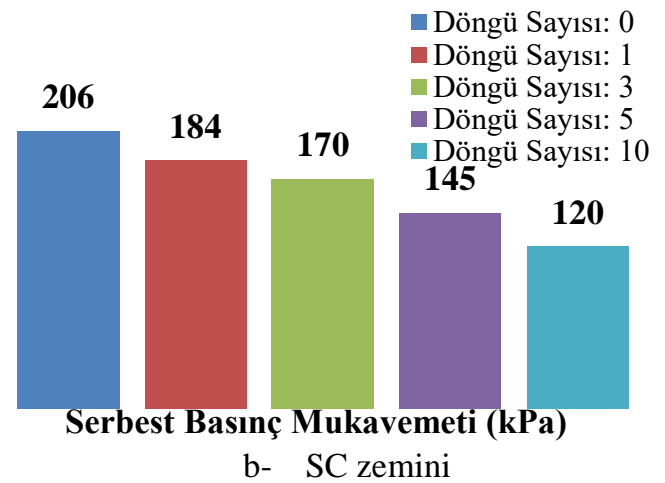

Şekil 6. Serbest basınç mukavemetleri

- Döngü Sayısı: 1

- Döngü Sayısı: 3

- Döngü Sayısı: 5

- Döngü Sayısi: 10

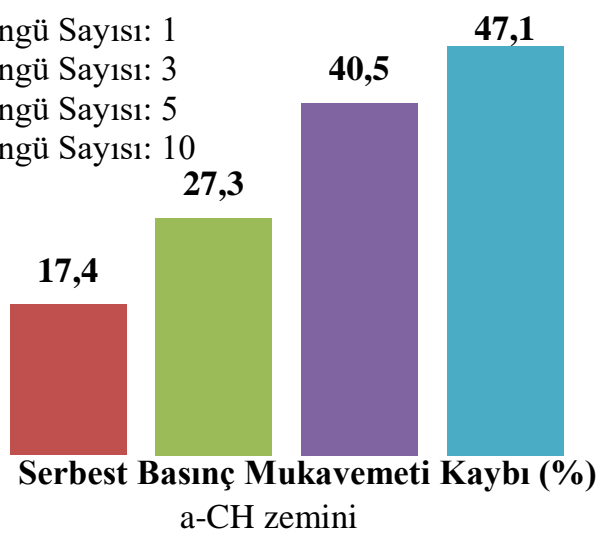

— Döngü Sayısı: 1

— Döngü Sayıs1: 3

- Döngü Sayıs1: 5

— Döngü Sayısı: 10

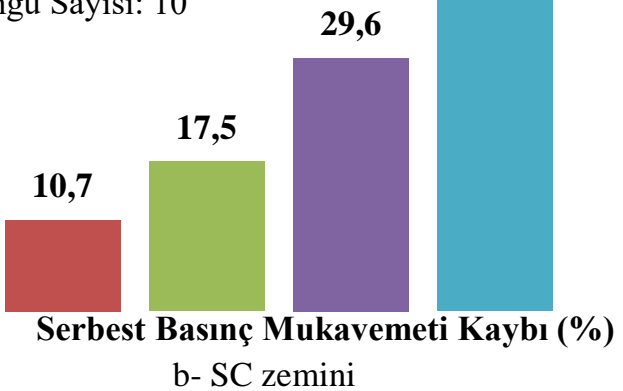

Şekil 7. Serbest basınç mukavemetlerindeki azalmalar
Şekil 8 ve Şekil 9'da, CH ve SC zeminlerinin farklı donma çözülme döngüleri sonrasında şişme basınçları ve şişme basınçlarındaki artma oranları görülmektedir. Artan döngü sayılarına bağlı olarak $\mathrm{CH}$ ve $\mathrm{SC}$ zeminleri için sirasiyla $3.3 \mathrm{kPa}$ 'dan $3.9 \mathrm{kPa}$ 'a ve $1.4 \mathrm{kPa}$ 'dan $1.6 \mathrm{kPa}$ 'a kadar şişme basınçları belirlenmiştir. Döngü sayısı arttıkça $\mathrm{CH}$ zemininde \% 3.9 ve SC için ise \% 1.6 oranlarında şişme basınçlarında artışlar meydana gelmiştir.

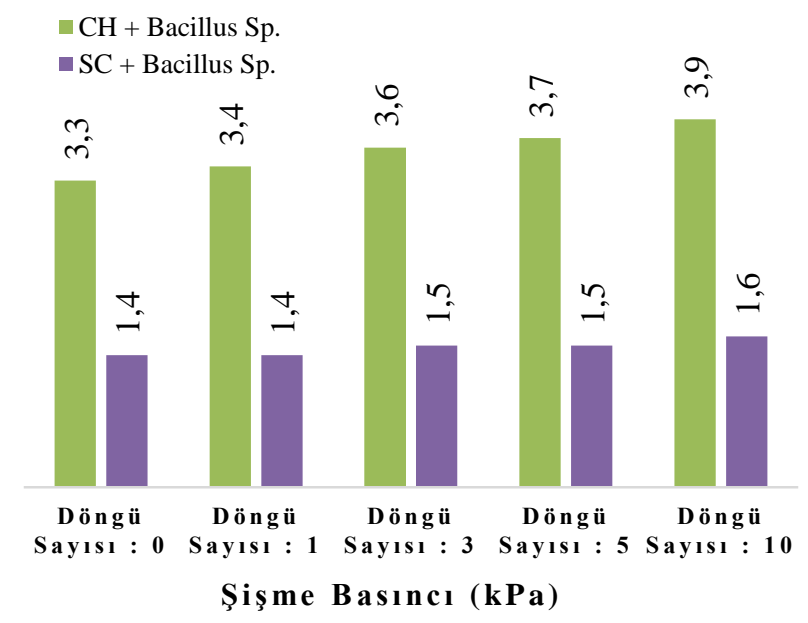

Şekil 8. Şişme basınçları

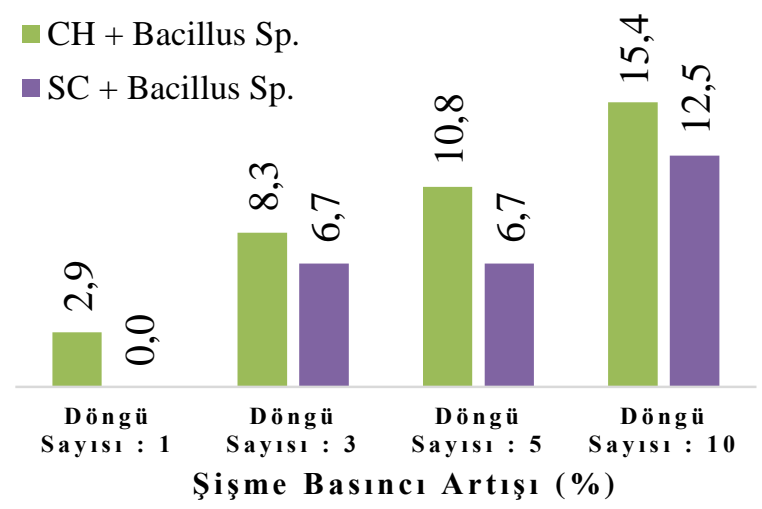

Şekil 9. Şişme basınçlarındaki artışlar

3.3 Bacillus sp. ile iyileştirilmiş ve iyileștirilmemiş zeminlerin mukavemet ve şişme basinc parametrelerinin karşılaştırılması

Şekil 10 ve Şekil 11'de, CH ve SC zeminlerinin farklı donma çözülme döngüleri sonrasında serbest basınç mukavemetleri ve mukavemet değerlerindeki azalma oranları görülmektedir. Sonuçlara bakıldığında, zeminler herhangi bir donma çözülme döngüsüne maruz bırakılmadan Bacillus $\mathrm{Sp}$, enjekte edilmesi sonucunda, $\mathrm{CH}$ zeminin mukavemeti $108 \mathrm{kPa}$ 'dan $121 \mathrm{kPa}$ 'a yükselerek \% 10.7 oranında artış gözlenmiștir. SC zeminin mukavemeti ise, aynı şartlar altında, $158 \mathrm{kPa}$ 'dan $206 \mathrm{kPa}$ 'a yükselerek \% 23.3 oranında artış meydana gelmiştir. Bacillus Sp. enjekte edilmiş her iki zemine bakıldığında $\mathrm{SC}$ zemininde $\mathrm{CH}$ zeminine göre \% 12.6 oranında fazladan iyileşme olduğu görülmüştür. Bunun sebebi olarak ise, Bacillus Sp.'nin SC zemininde daha fazla $\mathrm{CaCO}_{3}$ üretmesi olarak 
düşünülmektedir. SC zemininde dane boyutları $\mathrm{CH}$ zemininin dane boyutlarına göre bir miktar daha büyük olması nedeniyle, Bacillus Sp.'nin SC'nin boşluklarında daha aktif olarak $\mathrm{CaCO}_{3}$ üretim yapmasıdır. Üretilen $\mathrm{CaCO}_{3}$ ise her iki zeminin de bağlayıcılığını artırarak sadece $\mathrm{CH}$ ve SC zeminlerinin mukavemetlerine göre daha yüksek mukavemet göstermiștir. 1'den 10' a kadar artan donma çözülme döngülerinde, donma çözülme öncesi değerlere göre, $\mathrm{CH}$, SC, Bacillus Sp. enjekte edilmiş $\mathrm{CH}$ ve $\mathrm{SC}$ zeminlerinin mukavemet değerlerinde sırasıyla, \% 83.3, \% 88.6, \% 47.1 ve $\% 41.7$ oranlarında azalmalar gözlenmiştir. Her iki zemin içinde Bacillus Sp. tarafindan üretilen $\mathrm{CaCO}_{3}$ miktarına bağlı olarak her iki zeminin de bağlayıcılığının arttığı, buna bağlı olarak ta donma çözülme durumlarında daha kararlı bir zemin ortamı oluştuğu gözlenmiştir. Bu nedende de, Bacillus Sp.nin zeminlerin donma çözülme durumlarında da olumlu yönde katkısının olduğu ancak bu katkının zeminin cinsine göre farklılık gösterebileceği belirlenmiştir.

Şekil 12 ve Şekil 13'te, her iki zeminin farklı donma çözülme döngüleri sonrasında şişme basınçları ve bu

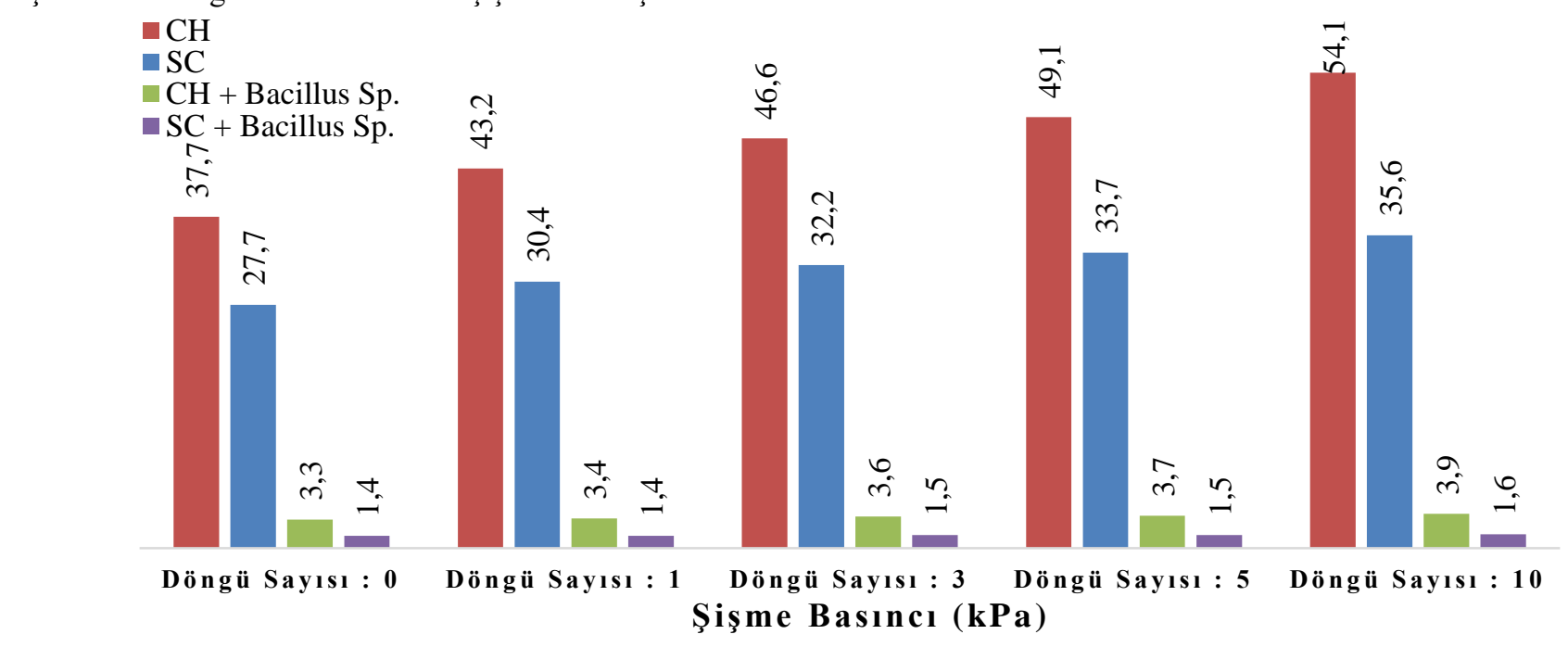

Şekil 10. Serbest basınç mukavemetlerinin karşılaştırılması basınçlardaki artma oranları görülmektedir. Sonuçlara bakıldığında, her iki zeminin de aynı döngüleri çin, Bacillus Sp. enjekte edilmesi ile şişme basınçlarının kayda değer oranlarda düştüğü gözlenmiştir. Ancak, SC zeminin de aynı döngü için $\mathrm{CH}$ zeminine göre şişme basıncının daha düşük olduğu belirlenmştir. Bunun sebebinin ise, Bacillus Sp.'nin SC zemininde daha fazla $\mathrm{CaCO}_{3}$ üretme ortamı bulmas1 olarak düşünülmüştür. $\mathrm{CaCO}_{3}$ miktarının fazla olması ile zeminin bağlayıcılık özelliğinin daha da arttığı buna bağlı olarak daha kararlı bir hale gelerek şişme basıncının kayda değer düştüğü gözlenmiştir. Artan donma çözülme döngülerinde ise, $\mathrm{CH}, \mathrm{SC}$, Bacillus Sp. enjekte edilmiş $\mathrm{CH}$ ve SC zeminlerinin şişme basınçlarında sırasıyla, \% 30.3, \% $22.3, \% 15.4$ ve $\% 12.5$ oranlarında artışlar gözlenmiştir. Bacillus Sp. enjekte edilmiş her iki zeminde de, enjekte edilmemiş durumlara göre şişme basınçlarındaki artışlarda iyileşmeler gözlenmiştir. Bacillus $\mathrm{Sp}$, enjektesinin zeminlerin donma çözülme durumlarında da olumlu etkisinin olduğu belirlenmiştir. Ancak, iyileşme derecesinin zemin cinsine göre farklılık gösterebileceği belirtilmiştir.

$$
\begin{aligned}
& =\mathrm{CH} \\
& \mathrm{SC} \\
& \mathrm{CH}+\text { Bacillus Sp. } \\
& \mathrm{SC}+\text { Bacillus Sp. }
\end{aligned}
$$

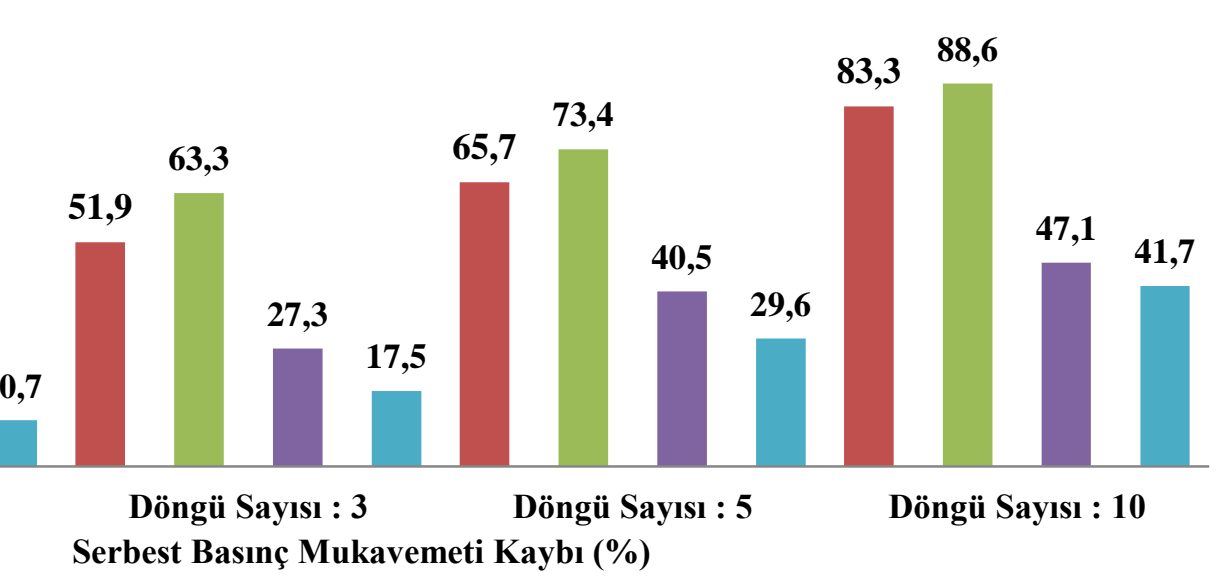

Şekil 11. Serbest basınç mukavemeti kaybı 


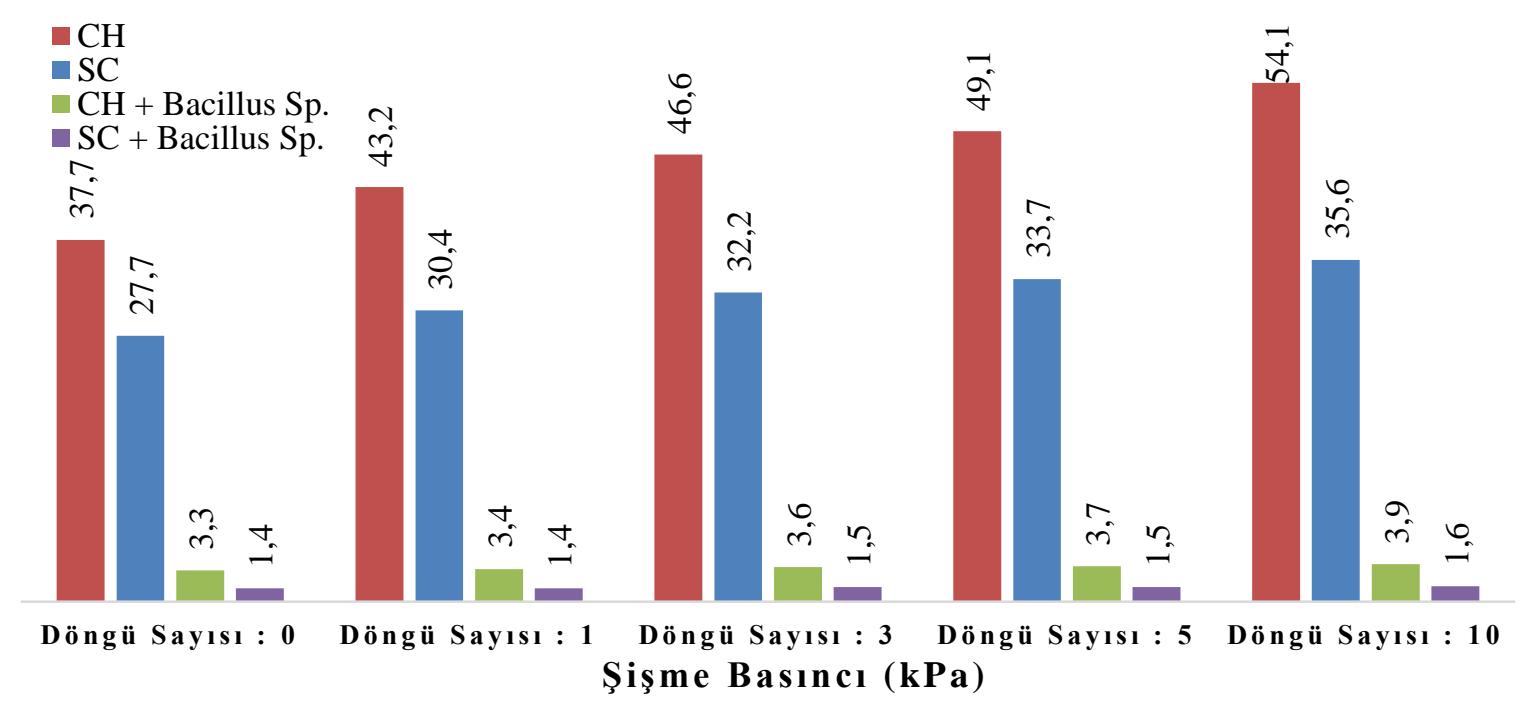

Şekil 12. Şişme basınçlarının karşılaştırılması
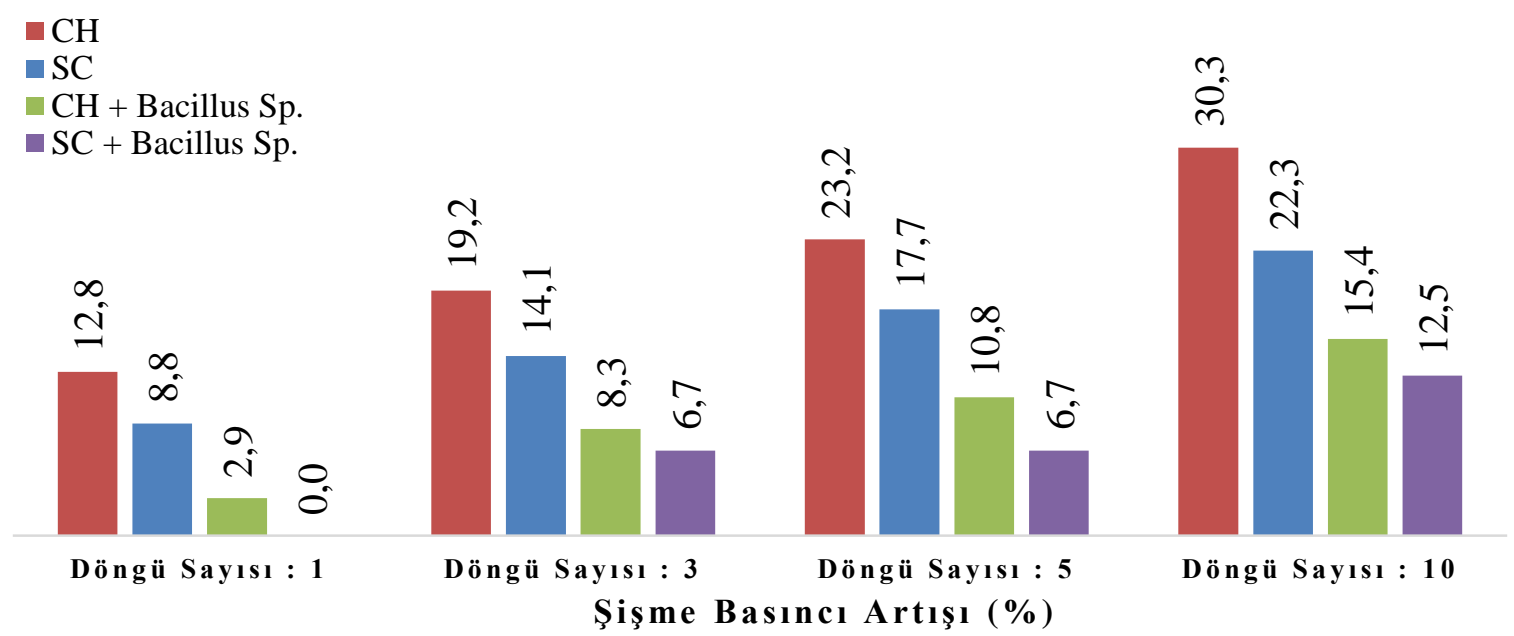

Şekil 13. Şişme basınçlarındaki artışlar

\section{Sonuçlar}

$\mathrm{Bu}$ çalı̧̧mada, $\mathrm{CH}$ ve $\mathrm{SC}$ türü zeminlerinin Bacillus $\mathrm{Sp}$. enjektesi ile iyileştirilebilirliğinin araştırılmasına yönelik bir seri mukavemet ve şişme basıncı deneyleri yapılmıştır. Deneylerden elde edilen sonuçlar aşağıdaki gibi özetlenmiştir.

1- $\quad \mathrm{CH}$ ve SC zemin numuneleri herhangi bir donma çözülme döngülerine maruz bırakılmadan serbest basınç mukavemetleri sırasıyla 108 ve $158 \mathrm{kPa}$ belirlenmiştir. SC türü zeminin dayanımının gradasyondaki dane boyutlarının büyük olmasından dolayı, $\mathrm{CH}$ zeminine göre daha yüksek çıkmıştır.

2- Artan donma çözülme döngü sayısına bağlı olarak, $\mathrm{CH}$ ve SC zeminlerinin mukavemet değerlerinde sirasıly \% 83.3 ve \% 88.6 oranlarında azalmalar gözlenmiştir. $\mathrm{Bu}$ azalmaların nedeni ise, numunelerin içindeki suyun donma anında hacminde artı̧s ve çözülme anında ise hacminde azalma meydana gelmesine bağlı olarak numunelerin danelerindeki tutunma özelliğinin azalmasından kaynaklandığı düşünülmektedir. Ayrıca，SC zemininin mukavemetinden daha fazla azalma olmasının sebebi ise, gradasyondaki dane boyutları büyük olduğundan daneler arasında daha fazla su tutmasına bağlı olarak donma çözülme döngüsünde, danelerin tutunma özelliklerinin daha fazla azalmasından kaynaklandığı düşünülmektedir.

3- $\mathrm{CH}$ ve SC zeminlerinin şişme basınçları artan döngü sayılarına bağlı olarak şişme basınçları sırasıyla 37.7 kPa'dan $54.1 \mathrm{kPa}^{\prime}$ a ve $27.7 \mathrm{kPa}$ 'dan $35.6 \mathrm{kPa}$ ' a kadar yükseldiği belirlenmiştir. $\mathrm{Bu}$ durumda, $\mathrm{CH}$ ve $\mathrm{SC}$ zeminlerinin şişme basıncı değerlerinde, sırasıyle $\% 30.3$ ve \% 22.3'e varan artışlar meydana gelmiştir. CH zemini içinde, ince dane oranının fazla olmasına bağlı olarak zemin içindeki suyun drenesinin SC zeminine göre daha da zorlaşmasından dolayı şişme basıncı değerlerinin daha da yüksek çıktı̆̆ı öngörülmüştür.

4- $\mathrm{CH}$ ve SC zeminlerine, Bacillus $\mathrm{Sp}$, enjekte edilmesi sonucunda, $\mathrm{CH}$ zeminin mukavemeti sirasiyla 108 $\mathrm{kPa}$ 'dan $121 \mathrm{kPa}$ 'a ve $158 \mathrm{kPa}$ 'dan $206 \mathrm{kPa}$ 'a yükselerek \% 10.7 ve \% 23.3 oranında artış meydana gelmiştir. Bacillus Sp. enjekte edilmiş zeminlerde $\mathrm{CaCO}_{3}$ üretimi olması nedeniyle danelerin bağlayıcılık özelliği artarak her iki zeminin de mukavemeti artmıştır. SC zemininde $\mathrm{CH}$ zeminine göre mukavemet değerinde \% 12.6 oranında 
fazladan artış olmasının sebebi, SC zemininde dane boyutları $\mathrm{CH}$ zemininin dane boyutlarına göre büyük olması nedeniyle, Bacillus Sp.'nin SC'nin boşluklarında daha aktif olarak $\mathrm{CaCO}_{3}$ üretim yapması olarak öngörülmüştür.

5- Donma çözülmeye maruz birakılan $\mathrm{CH}, \mathrm{SC}$, Bacillus Sp. enjekte edilmiş $\mathrm{CH}$ ve $\mathrm{SC}$ zeminlerinin mukavemet değerlerinde, donma çözülmesiz durumlara göre sirasiyla $\% 83.3, \% 88.6, \% 47.1$ ve $\% 41.7$ oranlarında azalmalar gözlenmiştir. Ayrıca, Bacillus Sp. enjekte edilmiş $\mathrm{CH}$ ve $\mathrm{SC}$ zeminlerinin, enjekte edilmemiş durumlara göre şişme basınçlarındaki artışların daha düşük oranlarda olduğu belirlenmiştir. Bacillus Sp. enjekte edilmiş zeminlerde $\mathrm{CaCO}_{3}$ üretimi ile zemin danelerinin bağlayıcılığı arttığı için Bacillus Sp.nin zeminlerin donma çözülme durumlarında da mukavemet ve şişme basınçları değerlerinde olumlu yönde katkısının olduğu anlaşılmıştır. Ancak bu olumlu yöndeki katkının zeminin cinsine göre farklılık gösterebileceği belirlenmiştir.

\section{Çıkar çatışması}

Yazarlar çıkar çatışması olmadığını beyan etmektedir.

\section{Benzerlik oranı (iThenticate): $\% 7$}

\section{Kaynaklar}

[1] H. Tremblay, D. Josée, L. Jacques, and L. Serge, Influence of the nature of organic compounds on fine soil stabilization with cement. Canadian Geotechnical Journal 39(3), 535-46, 2020. https://doi.org/ 10.1139/t02-002

[2] F. G. Bell, Lime stabilization of clay minerals and soils. Engineering geology 42(4), 223-37, 1996. https://doi.org/10.1016/0013-7952(96)00028-2

[3] A. Arulrajah, Y. Mohammadjavad, M.D. Mahdi, H. Suksun, W.B. Myint and L. Melvyn, Evaluation of fly ash-and slag-based geopolymers for the improvement of a soft marine clay by deep soil mixing. Soils and Foundations 58(6):1358-70, 2018. https://doi.org/ 10.1016/j.sandf.2018.07.005

[4] A. Kumar and P.V. Sivapullaiah, Improvement of strength of expansive soil with waste granulated blast furnace slag. In GeoCongress 2012: State of the Art and Practice in Geotechnical Engineering, 3920-8, 2012. https://doi.org/10.1061/9780784412121.402

[5] M. Kianimehr, T.S. Piltan, M.B.Seyed, M. Alireza and A. Arul, Utilization of recycled concrete aggregates for light-stabilization of clay soils. Construction and Building Materials 227, 116792, 2019. https://doi.org/10.1016/j.conbuildmat.2019.116792

[6] M.P. Bilondi, M.T. Mohammad and T. Vahid, Experimental investigation of using a recycled glass powder-based geopolymer to improve the mechanical behavior of clay soils. Construction and Building Materials 170, 302-13, 2018. https://doi.org/10.1016/ j.conbuildmat.2018.03.049

[7] A. Ateş, Mechanical properties of sandy soils reinforced with cement and randomly distributed glass fibers (GRC). Composites Part B: Engineering 96, 295-304, 2016. https://doi.org/10.1016/j.compositesb. 2016.04.049
[8] S. N. Esmaeilpour, T. G. Abbasali, K. T. Mohammadreza and J. C. Asskar, Improvement of the engineering behavior of sand-clay mixtures using kenaf fiber reinforcement. Transportation Geotechnics 19, 18, 2019. https://doi.org/10.1016/j.trgeo.2019.01.004

[9] O. Sivrikaya, F. Uysal, A. Yorulmaz and K. Aydın. The efficiency of waste marble powder in the stabilization of fine-grained soils in terms of volume changes. Arabian Journal for Science and Engineering, 45, 8561-8576, 2020. https://doi.org/10.1007/s13369-02004768-0

[10] A. Yorulmaz, O. Sivrikaya and F. Uysal, Evaluation of the bearing capacity of poor subgrade soils stabilized with waste marble powder according to curing time and freeze-thaw cycles. Arabian Journal of Geosciences, 14, 360, 2021. https://doi.org/10.1007/s12517-02106749-5

[11] K. Aydin, O. Sivrikaya and F. Uysal, Effects of curing time and freeze-thaw cycle on strength of soils with high plasticity stabilized by waste marble powder. J Mater Cycles Waste Manag 22, 1459-1474, 2020. https://doi.org/10.1007/s10163-020-01035-0

[12] J. T. Dejong, M. B. Fritzges and K. Nusslein. Microbially induced cementation to control sand response to undrained shear, J. Geotech. Geoenviron. Eng. 132, 1381-1392ASCE 1090-0241, 2006. https://doi.org/10.1061/(ASCE)10900241(2006)132:11(1381)

[13] S. Douglas, T.J. Beveridge, Mineral formation by bacteria in natural Communities, FEMS Microb. Ecol. 26, 79-88, 1998. https://doi.org/10.1111/j.15746941.1998.tb00494.x

[14] F. S. Stocks, J. K. Galinat and S. S. Bang, Microbiological precipitation of $\mathrm{CaCO}_{3}$, Soil Biol. Biochem. 31(11), 1563-1571, 1999. https://doi.org/ 10.1016/S0038-0717(99)00082-6

[15] J. T. Dejong, B. M. Mortensen, B. C. Martinez and D. C. Nelson, Biomediated soil improvement, Ecol. Eng., 36(2), 197-210, 2010. https://doi.org/10.1016/ j.ecoleng.2008.12.029

[16] S. S. Bang, J. K. Galinat and V. Ramakrishnan, Calcite precipitation induced by polyurethane-immobilized Sporosarcina pasteurii. Enzym. Microb. Technol. 28, 404-409, 2001. https://doi.org/10.1016/S01410229(00)00348-3

[17] V. S. Whiffin, L. A. van Paassen, and M. P. Harkes, Microbial carbonate precipitation as a soil improvement technique. Geomicrobiol. J. 25(5), 417423, 2007. https://doi.org/10.1080/0149045070 1436505

[18] H. Yasuhara, D. Neupane D., Hayashi K. and M. Okamura, Experiments and predictions of physical properties of sand cemented by enzymatically-induced carbonate precipitation, Soils and Foundations, 52(3), 539-549, 2012. https://doi.org/10.1016/j.sandf. 2012.05.011

[19] N. W. Soon, L. M. Lee, T. C. Khun and H. S. Ling, Improvements in engineering properties of soils through microbial-induced calcite precipitation, KSCE 
Journal of Civil Engineering, 17(4), 718-728, 2013. https://doi.org/10.1007/s12205-013-0149-8

[20] M. Nemati and G. Voordouw, Modification of porous media permeability, using calcium carbonate produced enzymatically in situ, Enzyme and Microbial Technology, 33(5), 635-642, 2003. https://doi.org/10.1016/S0141-0229(03)00191-1

[21] F. G. Ferris, L. G. Stehmeier, A. Kantzas and F. M. Mourits, Bacteriogenic mineral plugging, Journal of Canadian Petroleum Technology, 36 (9), 1997. https://doi.org/10.2118/97-09-07

[22] V. Ivanov and J. Chu, Applications of microorganisms to geotechnical engineering for bioclogging and biocementation of soil in situ, Reviews in Environmental Science and Biotechnology, 7(2), 139. 153, 2008. https://doi.org/10.1007/s11157-007-9126-3

[23] J. Chu, V. Stabnikov and V. Ivanov, Microbially induced calcium carbonate precipitation on surface or in the bulk of soil, Geomicrobiology Journal 29(6), 544-549, 2012. https://doi.org/10.1080/01490451. 2011.592929

[24] H. Canakci, W. Sidik, and I. H. Kilic, Effect of bacterial calcium carbonate precipitation on compressibility and shear strength of organic soil, Soils and Foundations, Part A 55(5), 1211-1221, 2015. https://doi.org/10.1016/j.sandf.2015.09.020

[25] TS 1500, İnşaat Mühendisliğinde Zeminlerin Sınıflandırılması. Türk Standartları Enstitüsü. Ankara, 2000 .
[26] M. Ghazavi and M. Roustaie, The influence of freezethaw cycles on the unconfined compressive strength of fiber-reinforced clay, Cold Regions Science and Technology, 61, 125-131, 2010. https://doi.org/ 10.1016/j.coldregions.2009.12.005

[27] J. Liu, T. Wang and Y. Tian, Experimental study of the dynamic properties of cement- and lime- modified clay soils subjected to freeze-thaw cycles. Cold Regions Science and Technology, 61, 29-33, 2010. https://doi.org/10.1016/j.coldregions.2010.01.002

[28] K. Hazirbaba, Y. Zhang, and J.L. Hulsey, Evaluation of temperature and freeze-thaw effects on excess pore pressure generation of fine-grained soils. Soil Dynamics and Earthquake Engineering, 31, 372-384, 2011. https://doi.org/10.1016/j.soildyn.2010.09.006

[29] A. Ş. Zaimoğlu, F. Hattatoğlu and R. K. Akbulut, Yüke maruz ince taneli zeminlerin donma-çözülme davranışı. Pamukkale Üniversitesi Mühendislik Bilimleri Dergisi, 19(3), 117-121, 2013. https://doi.org/10.5505/ pajes.2013.35744

[30] B. Mahmutluoğlu and B. Bağrıaçık, Killi zeminlerin donma-çözülme davranışlarında cam atık çamurunun etkisi. Çukurova Üniversitesi Mühendislik-Mimarlık Fakültesi Dergisi, 35(3) , 783-796, 2020. https://doi.org/10.21605/cukurovaummfd.846739

[31] TS 1900-2, İnşaat Mühendisliğinde Zemin Laboratuvar Deneyleri-Bölüm 2: Mekanik Özelliklerin Tayini. Türk Standartları Enstitüsü. Ankara, 2006. 